\title{
SOLID STATE INTERFACIAL REACTIONS IN A CERIA-COATED NI-BASED SUPERALLOY
}

\section{F. Pedraza*, B. Bouchaud}

fpedraza@univ-lr.fr

Université de La Rochelle. LaSIE, UMR-7356-CNRS. Avenue Michel Crépeau, 17042 La Rochelle cedex 01, FRANCE.

* Corresponding author:

Tel.: +33 (0) 546458297. Fax: +33(0) 546458241.

Email address: fpedraza@univ-lr.fr

\begin{abstract}
Perovskite type phases are known to improve the adherence of protective oxide scales grown onto chromia- and alumina-forming alloys and coatings. The present study investigates the interfacial reactions occurring during the high temperature oxidation of a ceria coated Ni-based superalloy at $1100^{\circ} \mathrm{C}$. The substrate firstly grew a duplex oxide scale with a $\mathrm{NiAl}_{2} \mathrm{O}_{4}$ spinel on top of an $\alpha-\mathrm{Al}_{2} \mathrm{O}_{3}$ scale underneath the ceria coating. Increasing oxidation time led to the development of Al-rich and Ce-rich nanometric grains at the oxide scale/coating interface and to the progressive vanishing of the $\mathrm{NiAl}_{2} \mathrm{O}_{4}$ spinel. Micro-Raman analyses demonstrated the formation of cerium aluminate $\mathrm{CeAlO}_{3}$ by solid-state reaction between $\mathrm{Al}_{2} \mathrm{O}_{3}$ and $\mathrm{CeO}_{2}$ favoured by an Al supply coming from the substrate. The results are in line with the thermodynamic calculations.
\end{abstract}

KEYWORDS: Ceria; Alumina; Perovskite; Solid-State Reaction; Oxidation; Coating.

\section{1.- INTRODUCTION}

The beneficial effect of the addition of rare-earth elements on the high temperature oxidation behaviour of chromia- and alumina-forming alloys and/or coatings has been widely reported and discussed in the literature [1-7]. Commonly agreed effects are that the addition of reactive elements alters the transformation kinetics of transient aluminas generally observed during early stages of oxidation and changes in the growing mechanisms of the oxide scale [1-7]. These modifications may lead to slower oxidation kinetics [8-10], reduced diffusion processes 
$[1,8,9,10]$, modification of the morphology and improvement the adherence of the oxide scales [11-17]. These phenomena have been ascribed to the segregation of reactive elements as single or mixed oxide at the oxide grain boundaries and at the metal/oxide interface [18-20]. Further, the formation of perovskite compounds is known to improve the adherence of protective oxide scales onto oxide-coated alumina-forming alloys [21,22]. Growth of (RE) $\mathrm{AlO}_{3}$ perovskite phases by solid state reactions at high temperature has been demonstrated for $\mathrm{Y}_{2} \mathrm{O}_{3}-$ and $\mathrm{Nd}_{2} \mathrm{O}_{3}-$ coated [21] and $\mathrm{Y}_{2} \mathrm{O}_{3}$-ODS [23] alumina-forming substrates. The perovskites improved the adherence of the oxide scale formed and blocked diffusion of the ionic species, hence resulting in overall improved oxidation resistance [24,25]. In some of our previous studies, the formation of $\mathrm{CeAlO}_{3}$ at the alumina/ceria interface was also considered to contribute to the enhanced adherence of the oxide scale of electrolytic $\mathrm{CeO}_{2}$ coatings on Ni-based superalloy substrates under isothermal and cyclic conditions [26-28] even after the application of water drops to embrittle the oxide/coating interface [29,30]. Nevertheless, despite favourable thermodynamic conditions, this was not clearly demonstrated experimentally.

In the open literature, few studies deal with growth of perovskites by reaction between $\mathrm{CeO}_{2}$ and $\alpha-\mathrm{Al}_{2} \mathrm{O}_{3}$ under oxidative atmosphere. Indeed, most of the investigations employed inert or reducing atmospheres to reduce $\mathrm{Ce}^{4+}$ and to favour the formation of the phase $\mathrm{CeAlO}_{3}$ by reacting with transition aluminas at high temperatures for catalytic applications [31-34]. Otherwise, synthesis of $\mathrm{CeAlO}_{3}$ by arc melting [35] and through wet methods and calcination of powders [36,37] have also been reported. Yet, it is worth mentioning that such experiments were carried out using free-standing powders precursors. In the particular case of $\mathrm{CeO}_{2}$-based coatings deposited onto a metallic substrate, solid state reactions will not only depend on the temperature and treatment duration and atmosphere but also strongly on the underlying substrate chemistry.

Therefore, the present study aims at understanding interfacial reactions during the oxidation of a ceria-coated Ni-based superalloy using Raman spectroscopy to emphasize the likely formation of mixed oxides supported by thermodynamic calculations.

\section{2.- MATERIALS AND METHODS}

Coupons (12 mm diameter, $2 \mathrm{~mm}$ thick) of grit blasted (220 mesh alumina) single-crystal René N5 Ni-based superalloy (composition given in Table 1) substrates were electrolytically coated with Ce hydroxides using a a three-electrode set-up for $20 \mathrm{~min}$ following the experimental conditions given in [26]. The coatings were subsequently annealed in flowing argon atmosphere 
at $1050^{\circ} \mathrm{C}$ for $1 \mathrm{~h}$ to enhance adherence and provide pre-oxidation of the substrate [38]. The ceria-coated superalloy substrates were then submitted to cyclic and isothermal oxidation at $1100^{\circ} \mathrm{C}$ in order to study the gas/solid heterogeneous oxidation mechanisms and the solid-state interfacial reactions.

Table 1.- Nominal composition (wt\%) of the René N5 Ni-based superalloy of this work.

\begin{tabular}{|c|c|c|c|c|c|c|c|c|}
\hline Ni & Cr & Co & Mo & W & Ta & Re & Al & Hf \\
\hline Bal. & 7 & 8 & 2 & 5 & 7 & 3 & 6.2 & 0.2 \\
\hline
\end{tabular}

The samples were characterized by X-ray diffraction in the Bragg-Brentano mode between 10 and $90^{\circ}$ (step size of $0.02^{\circ}$ for $2 \mathrm{~s}$ and slit sizes of $0.6 \mathrm{~mm}$ ) using a Bruker AXS D8 Advance $\left(\lambda_{\mathrm{Cu}}\right)$ and the surface and cross-sections were subsequently studied by Scanning Electron Microscopy coupled to EDS analyses (SEM/EDS, FEI Quanta 200F/EDAX). Likewise, local micro-Raman analyses were performed at room temperature to raster surfaces and crosssections with a Jobin Yvon Horibat LabRam HR Raman spectrometer equipped with a microscope and a Peltier-cooled CCD detector. The spectra were recorded with the acquisition software LabSpec with a resolution of $\sim 0.2 \mathrm{~cm}^{-1}$. Excitation was provided by a He-Ne laser source $(632.8 \mathrm{~nm})$. The laser power has been chosen in order to avoid local heating of the samples and provide sufficient good resolution [39]. The spot under the x50 objective was set to have a diameter lower than $3 \mu \mathrm{m}$.

The thermal events were studied with a SETARAM LabSys Evo TGA-DSC device by heating powder mixtures of $\mathrm{CeO}_{2}\left(<5 \mu \mathrm{m}, 99.9 \%\right.$ Sigma-Aldrich), $\mathrm{Al}_{2} \mathrm{O}_{3}$ (99.997\%, Sigma-Aldrich) and $\mathrm{Al}\left(5-6 \mu \mathrm{m} 99,99 \%\right.$, Sibthermochim) at $10^{\circ} \mathrm{C} \cdot \mathrm{min}^{-1}$ from $40^{\circ} \mathrm{C}$ to $1500^{\circ} \mathrm{C}$ under flowing argon gas $\left(20 \mathrm{~mL} \mathrm{~min}^{-1}\right)$ to limit oxidation. Thermodynamic calculations were also made using the HSC Chemistry thermodynamic software [40].

\section{3.- RESULTS AND DISCUSSION}

\section{1- As-coated condition}

The cross-section of the ceria-coated Ni-based superalloy substrate after thermal treatment at $1050^{\circ} \mathrm{C}$ in flowing argon atmosphere for $1 \mathrm{~h}$ is shown in Fig. 1 (a). The ceria coating exhibits a foam-like grainy microstructure with a micro-cracks network, some being open and leading directly to the coating/oxide scale interface. The full crystallization into the stoichiometric $\mathrm{CeO}_{2}$ fluorite form is also promoted, as suggested by the narrow $\mathrm{F}_{2 \mathrm{~g}}$ vibration typical of the $\mathrm{Ce}-\mathrm{O}$ bond of $\mathrm{CeO}_{2}$ in the Raman spectra [Fig. 1 (b)]. Underneath, the quick formation of a 
$\alpha-\mathrm{Al}_{2} \mathrm{O}_{3}$ phase together with traces of $\theta-\mathrm{Al}_{2} \mathrm{O}_{3}$ (Cr-fluorescence doublet [41]) is promoted by the Al supply from the $\gamma^{\prime}-\mathrm{Ni}_{3} \mathrm{Al}$ phase of the $\gamma / \gamma^{\prime}$ substrate. This results in depletion of $\gamma^{\prime}$ in the substrate (red line in Fig. 1(a)). The formation of an oxygen defective $\mathrm{CeO}_{2}$ coating lowers the oxygen partial pressure at the substrate/coating interface and allows the formation of the $\alpha$ $\mathrm{Al}_{2} \mathrm{O}_{3}$ as thoroughly explained by Pedraza et al. in [42].
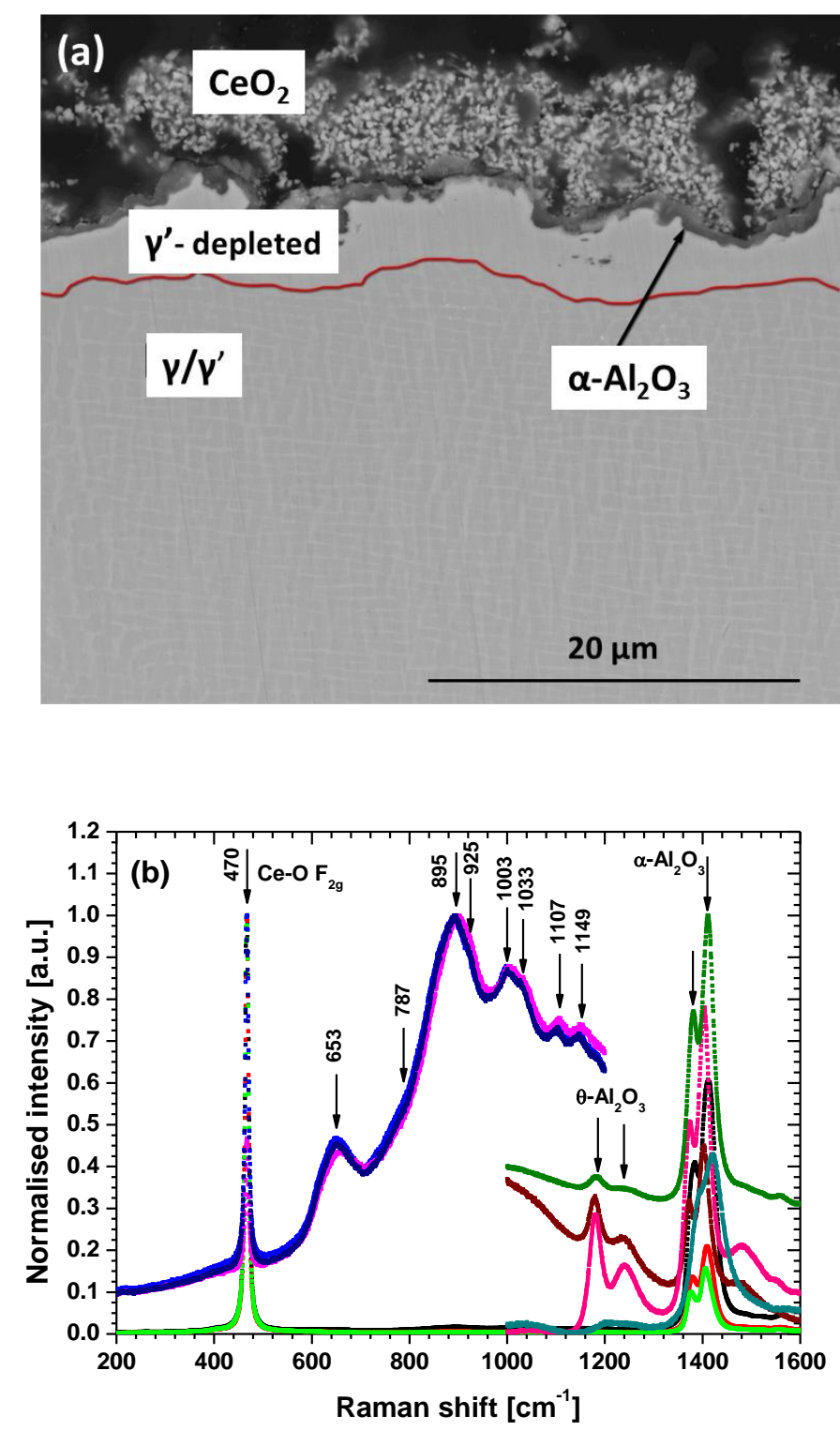

Fig. 1 - (a) Cross-section morphology and (b) overlapped surface Raman analyses of the $\mathrm{CeO}_{2}$-coated Ni-based superalloy after heat treatment at $1050^{\circ} \mathrm{C}$ for $1 \mathrm{~h}$ under flowing $\mathrm{Ar}$ atmosphere. NB: The overlapped spectra are taken in different areas for reproducibility purposes.

The surface Raman analyses of the interfacial oxide scale performed in the open cracks [Fig. 1 (b)] also suggest the presence of $\mathrm{NiAl}_{2} \mathrm{O}_{4}$ spinel phase on top of the alumina scale with its characteristic vibration bands between $600 \mathrm{~cm}^{-1}$ and $1100 \mathrm{~cm}^{-1}$. However, the $\mathrm{CeAlO}_{3}$ 
perovskite that Shyu et al. determined through a large fluorescence band underneath the $\mathrm{Ce}-\mathrm{O}$ vibration [43] is not observed in the areas with the open cracks [Fig. 1 (b)]. This would support our previous hypothesis in which we proposed that the solid-state reaction should only originate at the alumina/ceria interface [44].

\section{1- Coated and oxidized conditions}

The SEM cross-sections of ceria-coated samples showing the evolution of the oxide scale morphology after isothermal and cyclic oxidation at $1100^{\circ} \mathrm{C}$ up to $1000 \mathrm{~h}$ are presented in Fig. 2. Underneath the ceria coating, a duplex oxide scale quite similar to the one observed in Ptpoor $\gamma / \gamma^{\prime}$ or EQ coatings $[45,46]$ is evidenced. The scale consists in a top $\mathrm{NiAl}_{2} \mathrm{O}_{4}$ spinel phase, which grew mainly by nickel outward diffusion during the early stages of oxidation and before the establishment of a continuous and protective bottom $\alpha-\mathrm{Al}_{2} \mathrm{O}_{3}$ scale, as already demonstrated by Pedraza et al. using in-situ XRD diffraction [47]. With exposure time, the alumina subscale grows at the expense of the $\mathrm{NiAl}_{2} \mathrm{O}_{4}$ but the latter also detaches under cyclic conditions [28]. Once alumina gets in contact with ceria from the coating, an oxide interlayer presenting a nanograined morphology grows (detailed view in Fig. 2f). In one of our previous studies [28], we considered that this nanograined oxide could correspond to a $\mathrm{CeAlO}_{3}$ perovskite. This compound can be now confirmed by the presence of a large fluorescence band underneath the Ce-O vibration [Fig. 3 (a)] ascribed to $\mathrm{CeAlO}_{3}$ (perovskite type) by Shyu et al. [43]. In addition, the main signal of the oxide scale comes from the single $\alpha-\mathrm{Al}_{2} \mathrm{O}_{3}$ scale [Fig. 3(b)]. The small Raman shifts of the spinel fingerprints can be related to modifications of its lattice structure and composition.

Complementary tests were therefore performed by oxidizing mixtures of $\mathrm{Al}_{2} \mathrm{O}_{3}$ and $\mathrm{CeO}_{2}$ powders at $1100^{\circ} \mathrm{C}$ for $1 \mathrm{~h}, 3 \mathrm{~h}$ and $10 \mathrm{~h}$ under atmospheric pressure of air. The X-ray diffraction patterns of pure $\mathrm{CeO}_{2}, \mathrm{Al}_{2} \mathrm{O}_{3}$ and the mixtures $\mathrm{CeO}_{2}+\mathrm{Al}_{2} \mathrm{O}_{3}$ are shown overlapped in Fig. 4 for comparative purposes. It can be readily observed that no addition peaks related to the perovskite phases appear. 

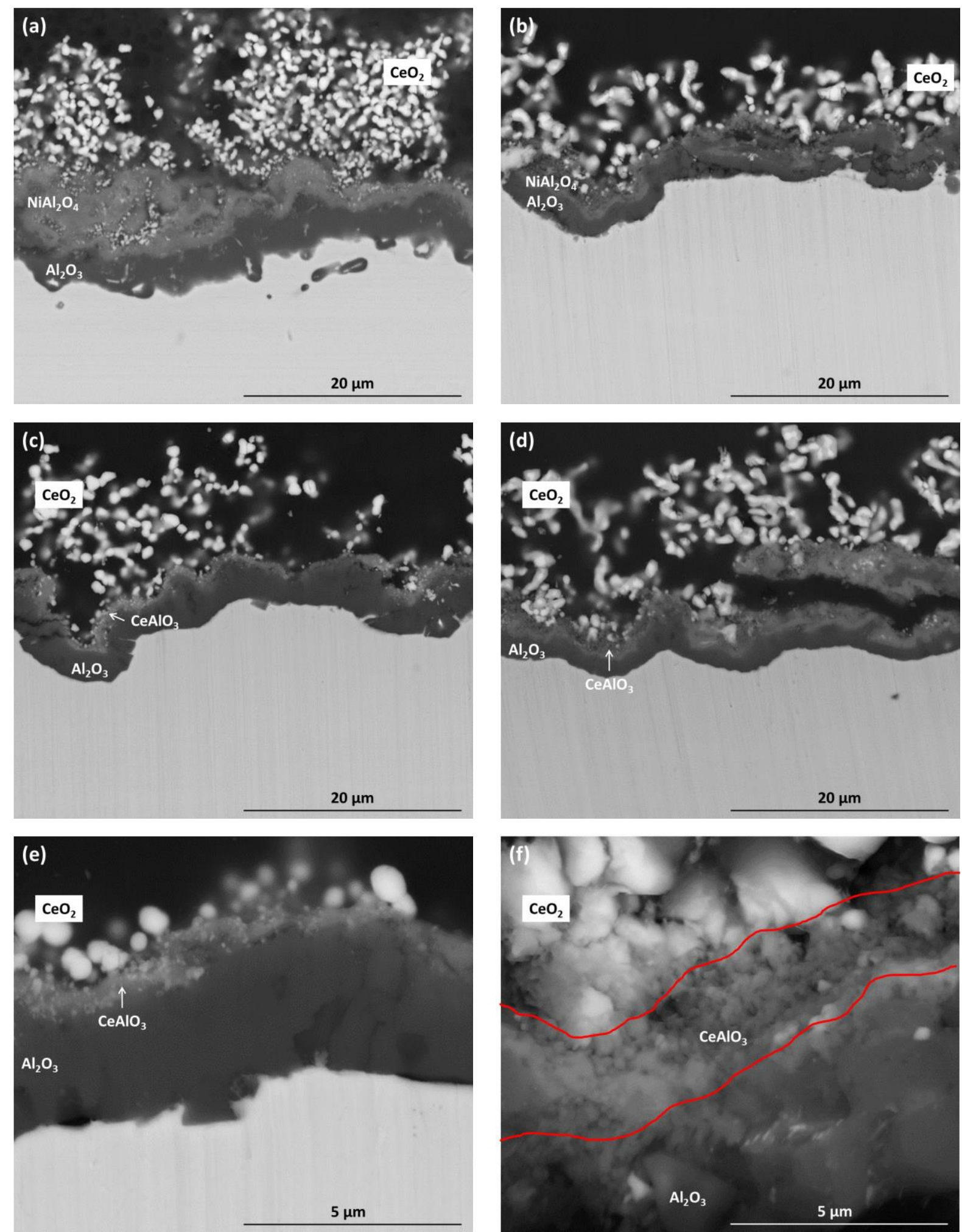

Fig. 2 - Cross-sections morphology after oxidation of $\mathrm{CeO}_{2}$-coated René N5 Ni-based superalloy at $1100^{\circ} \mathrm{C}$ up to $1000 \mathrm{~h}$ under isothermal (a,c,e) and cyclic conditions (b,d,f). (a) and (b): $500 \mathrm{~h}$ of oxidation. (c) and (d) $1000 \mathrm{~h}$ of oxidation. (e) and (f) are respectively, magnified views of (c) and (d). 

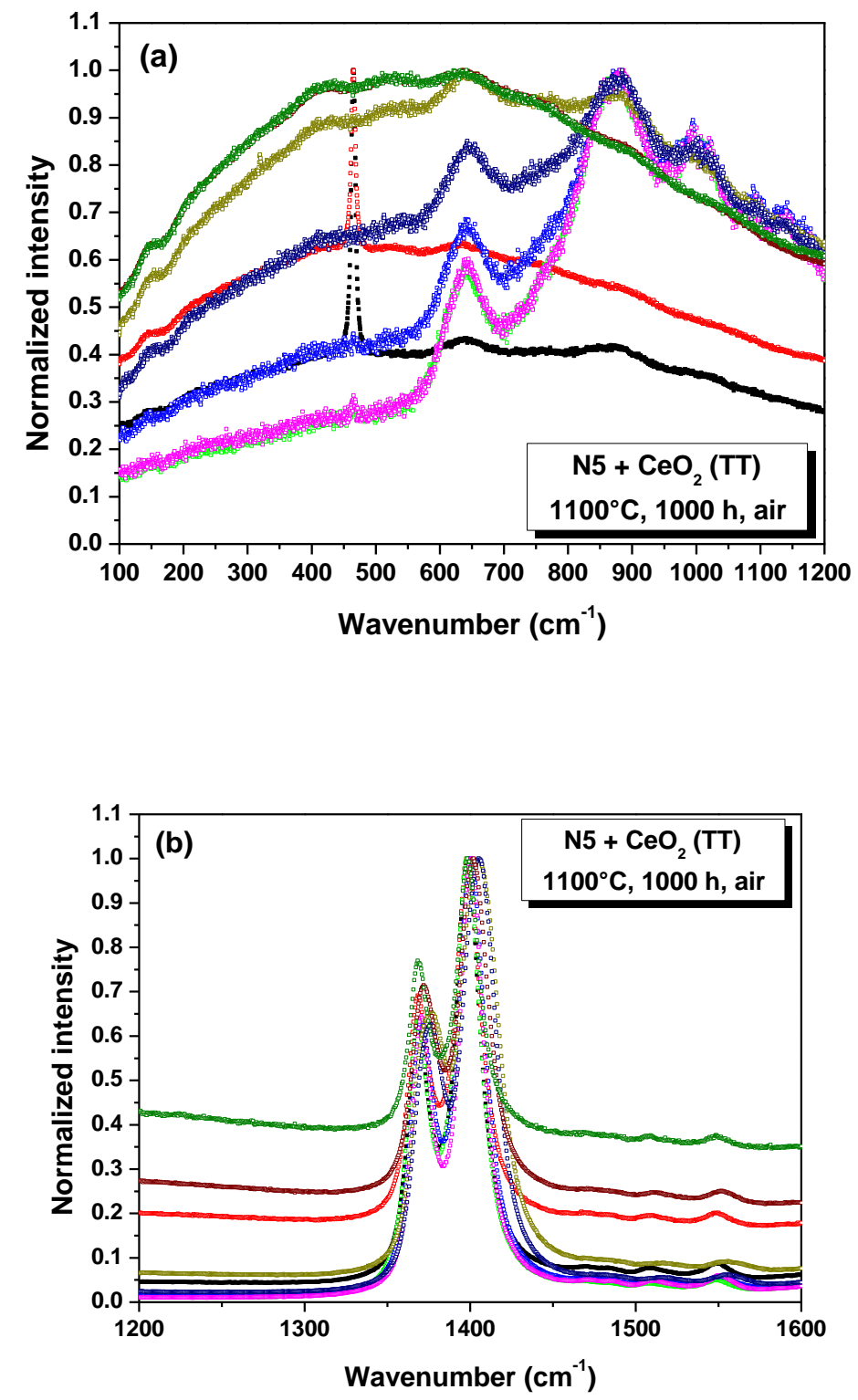

Fig. 3 - Raman cross-section analyses in the ceria-coated Ni-based superalloy substrate after $1000 \mathrm{~h}$ of oxidation at $1100^{\circ} \mathrm{C}$ in air under isothermal conditions (a) Raman domain, (b) fluorescence domain.

However, the thermodynamic calculations gathered in Figure 5(a) suggest the spontaneity of formation of $\mathrm{CeAlO}_{3}\left(\Delta_{r} G^{\circ}<0\right)$ according to equation (1).

$$
3 \mathrm{CeO}_{2}+\mathrm{Al}_{2} \mathrm{O}_{3}+\mathrm{Al} \rightarrow 3 \mathrm{CeAlO}_{3}
$$

One shall note that the reaction can only occur with additional input of $\mathrm{Al}$ from the underlying superalloy substrate to $\mathrm{CeO}_{2}$ and $\mathrm{Al}_{2} \mathrm{O}_{3}$. Therefore, DSC measurements were made with $\mathrm{Al}_{2} \mathrm{O}_{3} / \mathrm{CeO}_{2}$ and $\mathrm{Al}_{2} \mathrm{O}_{3} / \mathrm{CeO}_{2} / \mathrm{Al}$ powder mixtures up to $1500^{\circ} \mathrm{C}$ for two successive heating 
(annotated (1) and (2), respectively) and cooling (not presented for the sake of clarity) ramps (Figure 5b). The main thermal events from these DSC curves are gathered in Table 2.

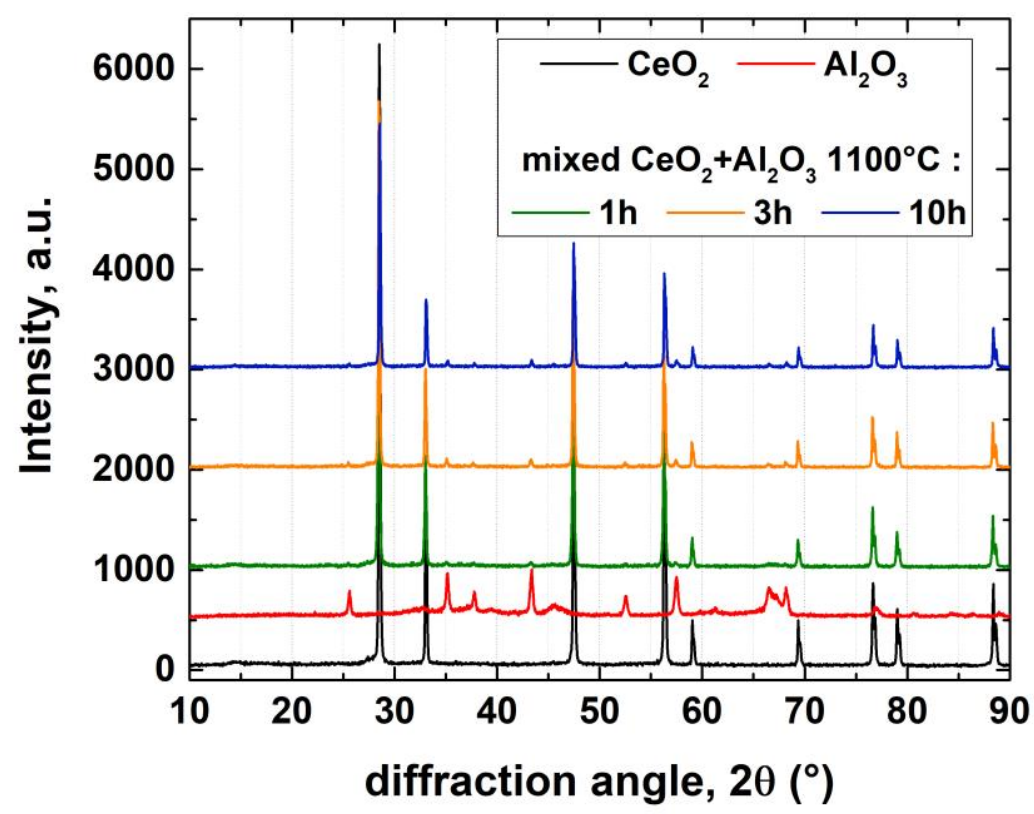

Fig. 4 - X-ray patterns of the pure $\mathrm{CeO}_{2}, \mathrm{Al}_{2} \mathrm{O}_{3}$ and the mixtures $\mathrm{CeO}_{2}+\mathrm{Al}_{2} \mathrm{O}_{3}$ after oxidation at $1100^{\circ} \mathrm{C}$ in air for 1,3 and $10 \mathrm{~h}$. Note that no other peaks than those of $\mathrm{CeO}_{2}$ and of $\mathrm{Al}_{2} \mathrm{O}_{3}$ appear.

In the absence of $\mathrm{Al}$ and for the first heating, the unstable $\gamma-\mathrm{Al}_{2} \mathrm{O}_{3}$ of the original powders is observed to transform into the stable $\alpha-\mathrm{Al}_{2} \mathrm{O}_{3}$ at a temperature close to the ones that Eisenreich et al. found for the transformations of both $\gamma$ - and $\theta-\mathrm{Al}_{2} \mathrm{O}_{3}$ grown in $\mathrm{Al}$ microparticles by high temperature XRD analysis [48]. Thereafter, the relatively weak exothermal event at $1170^{\circ} \mathrm{C}$ can be associated with the onset of the $\mathrm{CeAlO}_{3}$ decomposition according to reaction (2) [35]. This implies that a minor amount of $\mathrm{CeAlO}_{3}$ may have formed under the $\mathrm{Ar}$ atmosphere. This reaction also implies that sufficient oxygen is available, which can arise from the oxygen trapped in powders when mixed and put in the crucible. Upon the second heating, only one intense endothermic peak can be observed at $820^{\circ} \mathrm{C}$ that seem to shadow any other transformation. This peak can be attributed to the reduction of $\mathrm{CeO}_{2}$ as it coincides with the temperature value retrieved in the temperature-programmed reduction profiles of Piras and coll. [32].

$$
2 \mathrm{CeAlO}_{3}+1 / 2 \mathrm{O}_{2} \rightarrow 2 \mathrm{CeO}_{2}+\mathrm{Al}_{2} \mathrm{O}_{3}
$$



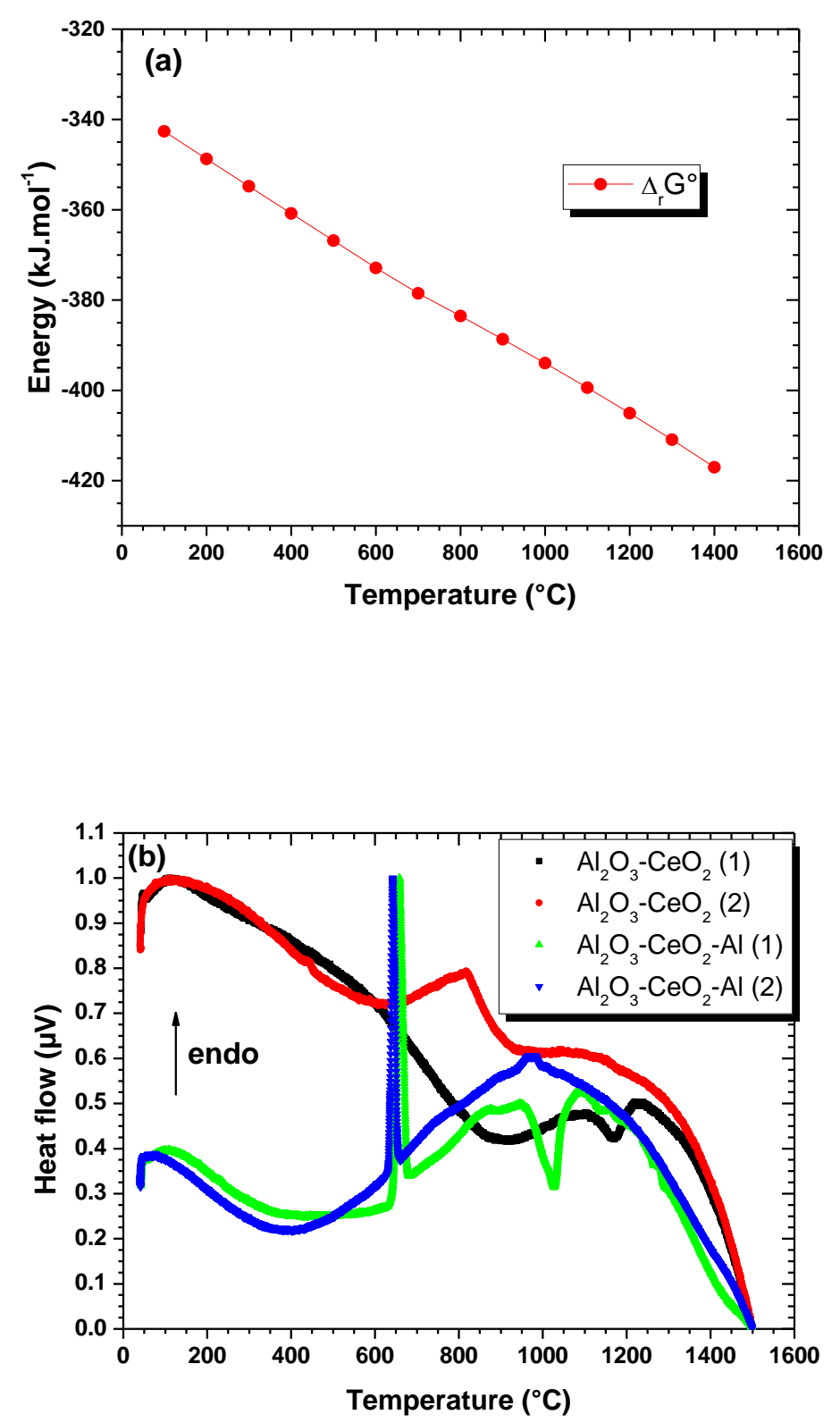

Fig. 5 - (a) HSC Thermodynamic calculation of free energy and heat release during the formation of $\mathrm{CeAlO}_{3}$ (eq. 1) and (b) DSC measurements of $\mathrm{Al}_{2} \mathrm{O}_{3} / \mathrm{CeO}_{2}$ and $\mathrm{Al}_{2} \mathrm{O}_{3} / \mathrm{CeO}_{2} / \mathrm{Al}$ powders mixtures heated up to $1500^{\circ} \mathrm{C}$ twice successively.

However, the addition of $\mathrm{Al}$ to the $\mathrm{CeO}_{2}$ and $\mathrm{Al}_{2} \mathrm{O}_{3}$ brings about many more thermal events, in particular upon the first heating. The melting temperature $\left(658^{\circ} \mathrm{C}\right)$ of $\mathrm{Al}$ lower than its theoretical one $\left(660^{\circ} \mathrm{C}\right)$ can result from the presence of impurities [49]. Like in the absence of $\mathrm{Al}$, the endotherm at $890^{\circ} \mathrm{C}$ is attributed to the transformation of $\gamma-\mathrm{Al}_{2} \mathrm{O}_{3}$ into $\alpha-\mathrm{Al}_{2} \mathrm{O}_{3}$ that is fully stabilized at about $1026^{\circ} \mathrm{C}$ [48]. The increase of temperature results again in the onset of the decomposition of $\mathrm{CeAlO}_{3}$. However, the thermal exchange (amplitude of the peak) is far less marked than in the absence of Al. This can be due to the shadowing of the peak at $1026^{\circ} \mathrm{C}$ 
but also to a greater stabilization of the $\mathrm{CeAlO}_{3}$ in the presence of $\mathrm{Al}$. The second hypothesis can be confirmed upon the second heating with a strong endotherm at $965^{\circ} \mathrm{C}$ related to the formation of $\mathrm{CeAlO}_{3}$ that Piras and collab. observed at $950^{\circ} \mathrm{C}$ upon the reaction of $15 \% \mathrm{CeO}_{2}$ with $\mathrm{Al}_{2} \mathrm{O}_{3}$ [32], i.e. less $\mathrm{CeO}_{2}$ than in our study. Further, the melting temperature of $\mathrm{Al}$ decreases further $\left(654^{\circ} \mathrm{C}\right)$ probably by concentration of the impurities after cooling.

Table 2.- Thermal data for the corresponding DSC curves plotted in Figure $4 \mathrm{~b}$.

\begin{tabular}{|c|c|c|c|}
\hline System & $T_{\max } \pm 2\left({ }^{\circ} \mathrm{C}\right)$ & Type & Transformation \\
\hline \multirow{2}{*}{$\mathrm{Al}_{2} \mathrm{O}_{3}+\mathrm{CeO}_{2}(1)$} & 890 & endo & $\gamma-\mathrm{Al}_{2} \mathrm{O}_{3}$ into $\alpha-\mathrm{Al}_{2} \mathrm{O}_{3}[48]$ \\
\hline & 1170 & exo & Onset of $\mathrm{CeAlO}_{3}$ decomposition [35] \\
\hline $\mathrm{Al}_{2} \mathrm{O}_{3}+\mathrm{CeO}_{2}(2)$ & 820 & endo & Reduction of $\mathrm{CeO}_{2}[32]$ \\
\hline \multirow{4}{*}{$\mathrm{Al}_{2} \mathrm{O}_{3}+\mathrm{CeO}_{2}+\mathrm{Al}(1)$} & 658 & endo & Melting of Al [49] \\
\hline & 890 & endo & $\gamma-\mathrm{Al}_{2} \mathrm{O}_{3}$ into $\alpha-\mathrm{Al}_{2} \mathrm{O}_{3}[48]$ \\
\hline & 1026 & exo & Full stabilization of $\alpha-\mathrm{Al}_{2} \mathrm{O}_{3}$ [48] \\
\hline & 1160 & exo & Onset of $\mathrm{CeAlO}_{3}$ decomposition [35] \\
\hline \multirow{2}{*}{$\mathrm{Al}_{2} \mathrm{O}_{3}+\mathrm{CeO}_{2}+\mathrm{Al}(2)$} & 654 & endo & Melting of unmolten Al [49] \\
\hline & 965 & exo & Formation of $\mathrm{CeAlO}_{3}[32]$ \\
\hline
\end{tabular}

\section{CONCLUSIONS}

The oxidation of a $\mathrm{CeO}_{2}$-coated nickel-based superalloy at $1100^{\circ} \mathrm{C}$ resulted in the growth of an interfacial $\mathrm{CeAlO}_{3}$ perovskite phase between the upper $\mathrm{CeO}_{2}$ and the lower $\mathrm{Al}_{2} \mathrm{O}_{3}$. The DSC carried out with the mixed powders of $\mathrm{CeO}_{2}$ and $\mathrm{Al}_{2} \mathrm{O}_{3}$ (and $\mathrm{Al}$ ) in $\mathrm{Ar}$ (i.e. low oxygen partial pressure) demonstrates that the interfacial pressure underneath the coating shall be also sufficiently low. The DSC results are in line with the thermodynamic calculations and with the observations by microscopy and the Raman analyses. The growth of $\mathrm{CeAlO}_{3}$ is facilitated with additional Al supply from the substrate. This requires extended exposure at temperature and reduced oxygen partial pressure at the $\mathrm{CeO}_{2}$ coating/ $\mathrm{Al}_{2} \mathrm{O}_{3}$ oxide interface and the concomitant disappearance of $\mathrm{NiAl}_{2} \mathrm{O}_{4}$. The resulting perovskite is made of nanograins. Further transmission electron microscopy studies could be thus performed consolidate our findings.

\section{REFERENCES}


[1] J. Stringer, I.G. Wright, The high-temperature oxidation of cobalt-21 wt.\% chromium-3 vol.\% $\mathrm{Y}_{2} \mathrm{O}_{3}$ alloys, Oxid. Met. 5 (1972) 59-84. https://doi.org/10.1007/BF00614619

[2] P.Y. Hou, J. Stringer, The effect of reactive element additions on the selective oxidation, growth and adhesion of chromia scales. Mater. Sci. Eng. A202 (1995) 1-10. https://doi.org/10.1016/0921-5093(95)09798-8

[3] F.H. Stott, The Oxidation of Alumina-Forming Alloys. Mat. Sci. Forum 251 (1997) 19-32. https://doi.org/10.4028/www.scientific.net/MSF.251-254.19

[4] F.J. Pérez, M.J. Cristobal, M.P. Hierro, F. Pedraza, G. Arnau, T.P. Merino, Effect of yttrium and erbium ion implantation on the oxidation behaviour of the AISI 304 austenitic steel. Surf. Coat. Technol. 126 (2000) 116-122. https://doi.org/10.1016/S0257-8972(99)00666-0

[5] X. Peng, T. Li, W.P. Pan, Oxidation of a $\mathrm{La}_{2} \mathrm{O}_{3}$-modified aluminide coating. Scripta Mater. 44 (2001) 1033-1038. https://doi.org/10.1016/S1359-6462(01)00666-2

[6] B.A. Pint, K.L. More, I.G. Wright, Effect of quaternary additions on the oxidation behavior of Hf-doped NiAl. Oxid. Met. $59 \quad$ (2003) 257-283. https://doi.org/10.1023/A:1023087926788

[7] D. Naumenko, V. Kochubey, J. Le-Coze, E. Wessel, L. Singheiser, W.J. Quadakkers, Effect of combined yttrium and zirconium additions on protective alumina scale formation on high purity $\mathrm{FeCrAl}$ alloys during oxidation in the temperature range of 1200 to $1300^{\circ} \mathrm{C}$. Mater. Sci. Forum 461 (2004) 489-496. https://doi.org/10.4028/www.scientific.net/MSF.461$\underline{464.489}$

[8] D.P. Whittle, J. Stringer, Improvements in high temperature oxidation resistance by additions of reactive elements or oxide dispersions. Phil. Trans. R. Soc. Lond. A295 (1980) 309-329. https://doi.org/10.1098/rsta.1980.0124

[9] V.K. Tolpygo, J.R. Dryden, D.R. Clarke, Determination of the growth stress and strain in $\alpha-\mathrm{Al}_{2} \mathrm{O}_{3}$ scales during the oxidation of $\mathrm{Fe}-22 \mathrm{Cr}-4.8 \mathrm{Al}-0.3 \mathrm{Y}$ alloy. Acta Mater. 46 (1998) 927-937. https://doi.org/10.1016/S1359-6454(97)00306-6

[10] B. Pieraggi, R.A. Rapp, Chromia Scale Growth in Alloy Oxidation and the Reactive Element Effect. J. Electrochem. Soc. $140 \quad$ (1993) 2844-2850. https://doi.org/10.1149/1.2220920

[11] C.H. Xu, W. Gao, D. Li, Oxidation behaviour of FeAl intermetallics - the effect of Y on the scale spallation resistance. Corros. Sci. 43 (2001) 671-688. https://doi.org/10.1016/S0010-938X(00)00104-9

[12] A.W. Funkenbusch, J.G. Smeggil, N.S. Bornstein, Reactive element-sulfur interaction and oxide scale adherence. Metall. Trans. A16 (1985) 1164-1166. https://doi.org/10.1007/BF02811687 
[13] J. Jedlinski, The oxidation behaviour of FeCrAl 'alumina forming' alloys at high temperatures. Solid State Ionics 101 (1997) 1033-1040. https://doi.org/10.1016/S0167$\underline{\text { 2738(97)00299-3 }}$

[14] J.L. Smialek, J. Doychak, D.J. Gaydosch, Oxidation behavior of FeAl+Hf, Zr, B. Oxid. Met. 34 (1990) 259-275. https://doi.org/10.1007/BF00665018

[15] C.H. Xu, W. Gao, H. Gong, Oxidation behaviour of FeAl intermetallics. The effects of $\mathrm{Y}$ and/or $\mathrm{Zr}$ on isothermal oxidation kinetics. Intermetallics 8 (2000) 769-779. https://doiorg.gutenberg.univ-lr.fr/10.1016/S0966-9795(00)00007-8

[16] J. Jedlinski, Comments on the effect of yttrium on the early stages of oxidation of alumina formers. Oxid. Met. 39 (1993) 55-60. https://doi.org/10.1007/BF00666609

[17] S. Chevalier, G. Strehl, H. Buscail, G. Borchardt, J.P. Larpin, Influence of the mode of introduction of a reactive element on the high temperature oxidation behavior of an alumina forming alloy. Part I: Isothermal oxidation tests. Mater. Corr. 55 (2004) 352-357. https://doi.org/10.1002/maco.200303748

[18] B.A. Pint, J.R. Martin, L.W. Hobbs, ${ }^{18} \mathrm{O} / \mathrm{SIMS}$ characterization of the growth mechanism of doped and undoped $\alpha-\mathrm{Al}_{2} \mathrm{O}_{3}$. Oxid. Met. 39 (1993) 167-195. https://doi.org/10.1007/BF00665610

[19] B.A. Pint, Experimental observations in support of the dynamic-segregation theory to explain the reactive-element effect. Oxid. Met. 45 (1996) 1-37. https://doi.org/10.1007/BF01046818

[20] B.A. Pint, K.B. Alexander, Grain Boundary Segregation of Cation Dopants in $\alpha-\mathrm{Al}_{2} \mathrm{O}_{3}$ Scales. J. Electrochem. Soc. 145 (1998) 1819-1829. https://doi.org/10.1149/1.1838563

[21] S. Chevalier, C. Nivot and J.P. Larpin, Influence of reactive element oxide coatings on the high temperature oxidation behavior of alumina-forming alloys. Oxid. Met. 61 (2004) 195-217. https://doi.org/10.1023/B:OXID.0000025331.25452.35

[22] J.-M. Brossard, J. Balmain, A.M. Huntz, G. Bonnet, Effect of electrodeposited thin films containing yttrium on high temperature oxidation behaviour of Ni base alloys. Mater. Sci. Forum 461 (2004) 327-334. https://doi.org/10.4028/www.scientific.net/MSF.461-464.327

[23] F. Pedraza, J.L. Grosseau-Poussard and J.F. Dinhut, Evolution of oxide scales on an ODS FeAl intermetallic alloy during high temperature exposure in air. Intermetallics 13 (2005) 27-33. https://doi.org/10.1016/j.intermet.2004.04.042

[24] M.C. Garcia-Alonso, J.L. Gonzalez-Carrasco, P. Pérez, V.A.C. Haannappel, M.L. Escudero, J. Chao, M.F. Stroosnijder, A surface modified ODS superalloy by thermal oxidation for potential implant applications. J. Mater. Sci.: Mater. Med. 12 (2001) 589-596. https://doi.org/10.1023/A:1011281425321 
[25] C. Mennicke, E. Schumann, M. Rühle, R.J. Hussey, G.I. Sproule, M.J. Graham, The effect of yttrium on the growth process and microstructure of $\alpha-\mathrm{Al}_{2} \mathrm{O}_{3}$ on FeCrAl. Oxid. Met. 49 (1999) 455-466. https://doi.org/10.1023/A:1018803113093

[26] F. Pedraza, B. Bouchaud, J. Balmain, G. Bonnet, J. Menuey, Electrosynthesis of Rare Earth Oxide Coatings for High Temperature Applications. Mater. Sci. Forum 696 (2001) 336-341. https://doi.org/10.4028/www.scientific.net/MSF.696.336

[27] B. Bouchaud, J. Balmain, G. Bonnet, F. Pedraza, Correlations between electrochemical mechanisms and growth of ceria based coatings onto nickel substrates. Electrochim. Acta, 88 (2013) 798- 806. https://doi.org/10.1016/j.electacta.2012.10.112

[28] B. Bouchaud, F. Pedraza, Oxidation behaviour of new electrolytically synthesized ceria modified platinum $\gamma / \gamma^{\prime}$ coatings. Surf. Coating. Technol. 248 (2014) 74-80. https://doi.org/10.1016/j.surfcoat.2014.03.034

[29] B. Bouchaud, J. Balmain, D. Barrere, T. Delannoye, F. Pedraza, Effect of water drops on the oxidation mechanisms of a ceria coated nickel-based superalloy. Corros. Sci. 68 (2013) 176-185. https://doi.org/10.1016/j.corsci.2012.11.010

[30] M. Brossard, B. Bouchaud, G. Bonnet, B. Rannou, F. Pedraza, Early stages of high temperature cyclic oxidation of an electrodeposited ceria coating on nickel superalloys under water-drop tests. Oxid. Met.81 (2014) 95-104. https://doi.org/10.1007/s11085-013$\underline{9426-7}$

[31] Q. Zhang, F. Saito, Mechanochemical synthesis of lanthanum aluminate by grinding lanthanum oxide with transition alumina. J. Am. Ceram. Soc. 83 (2000) 439-441. https://doi.org/10.1111/j.1151-2916.2000.tb01215.x

[32] A. Piras, A. Trovarelli, G. Dolcetti, Remarkable stabilization of transition alumina operated by ceria under reducing and redox conditions. Appl. Cat. B: Env. 28 (2000) L77L81. https://doi.org/10.1016/S0926-3373(00)00226-5

[33] W.T. Fu, D.J.W. Ijdo, The structure of $\mathrm{CeAlO}_{3}$ by Rietveld refinement of X-ray powder diffraction data. J. Solid State Chem. 177 (2004) 2973-2976. https://doi.org/10.1016/j.jssc.2004.04.056

[34] A. Piras, S. Colussi, A. Trovarelli, V. Sergo, J. Llorca, R. Psaro and L. Sordelli, structural and morphological investigation of ceria-promoted $\mathrm{Al}_{2} \mathrm{O}_{3}$ under severe reducing/oxidizing conditions. J. Phys. Chem. B 109 (2005) 11110-11118. https://doi.org/10.1021/jp0440737

[35] T. Shishido, Y. Zheng, A. Saito, H. Horiuchi, K. Kudouc, S.Okada, T. Fukuda, Microstructure, thermal properties and hardness of the $\mathrm{CeMO}_{3}(\mathrm{M}=\mathrm{Al}, \mathrm{Ga})$ synthesized by 
arc-melting method. J. Alloy Compd. 260 (1997) 88-92. https://doi.org/10.1016/S0925$\underline{8388(97) 00141-2}$

[36] S. A. Venancio, P.E. V. de Miranda, Synthesis of $\mathrm{CeAlO}_{3} / \mathrm{CeO}_{2}-\mathrm{Al}_{2} \mathrm{O}_{3}$ for use as a solid oxide fuel cell functional anode material. Ceram. Intl. 37 (2011) 3139-3152. https://doi.org/10.1016/j.ceramint.2011.05.054

[37] S. Pradhan, U. Gupta, S. Chilukuri. Low Temperature Synthesis of $\mathrm{CeAlO}_{3}$ Perovskites. Adv. Porous Mater. 4 (2016) 73-78. https://doi.org/10.1166/apm.2016.1097

[38] B. Bouchaud, J. Balmain, G. Bonnet, F. Pedraza: "Optimizing structural and compositional properties of electrodeposited ceria coatings for enhanced oxidation resistance of a nickel-based superalloy". Applied Surface Science 268 (2013) 218- 224. https://doi.org/10.1016/j.apsusc.2012.12.065

[39] G. Calvarin, A.M. Huntz, A. Hugot Le Goff, S. Joiret, M.C. Bernard, Oxide scale stress determination by Raman spectroscopy: Application to the $\mathrm{NiCr} / \mathrm{Cr}_{2} \mathrm{O}_{3}$ system and influence of yttrium. Scripta Mater. 38 (1998) 1649-1658. https://doi.org/10.1016/S1359$\underline{6462(98) 00079-7}$

[40] A. Roine, HSC Chemistry for Windows version 3.02, Outokumpu Research Oy, Pori, Finland, 2004.

[41] Q. Wen, D.M. Lipkin, D.R. Clarke, Luminescence characterization of chromiumcontaining theta-alumina. J. Am. Ceram. Soc. 81 (1998) 3345-3348. https://doi.org/10.1111/j.1151-2916.1998.tb02781.x

[42] F. Pedraza, J. Balmain, G. Bonnet, B. Bouchaud, Novel concept of functional oxide coatings providing enhanced oxidation resistance to Ni-based superalloys. MRS Bull. 49 (2014) 384-387. https://doi.org/10.1016/j.materresbull.2013.09.017

[43] J.Z. Shyu, W.H. Weber, H.S. Gandhi, Surface characterization of alumina-supported ceria. J. Phys. Chem. 92 (1988) 4964-4970. https://doi.org/10.1021/j100328a029

[44] F. Pedraza, B. Bouchaud, J. Balmain, G. Bonnet, J. Menuey, Enhanced cyclic oxidation resistance of a single crystal superalloy with an electrodeposited reactive element oxide $\begin{array}{llllll}\text { coating. } & \text { Mater. } & \text { Sci. } & \text { Forum } & 696 & \text { (2011) }\end{array}$ https://doi.org/10.4028/www.scientific.net/MSF.696.278

[45] A. Sato, H. Harada, K. Kawagishi, Development of a new bond coat "EQ coating" system. Metall. Mat. Trans. A: Phys. Metall. Mat. Sci. 37 (2006) 789-790. https://doi.org/10.1007/s11661-006-0050-X

[46] T. Izumi, N. Mu, L. Zhang, B. Gleeson, Effects of targeted $\gamma-\mathrm{Ni}+\gamma^{\prime}-\mathrm{Ni}_{3}$ Al-based coating compositions on oxidation behaviour. Surf. Coat. Technol. 202 (2007) 628-631. https://doi.org/10.1016/j.surfcoat.2007.08.014 
[47] F. Pedraza, B. Bouchaud, J. Balmain, G. Bonnet, V. Kolarik, J. Menuey, On the development of a protective oxide system in rare earth oxide coated nickel superalloy under isothermal oxidation conditions. Mater. Sci. Forum 696 (2011) 284-289. https://doi.org/10.4028/www.scientific.net/MSF.696.284

[48] N. Eisenreich, H. Fietzek, M.M. Juez-Lorenzo, V. Kolarik, A. Koleczko, V. Weiser, On the mechanism of low temperature oxidation for aluminum particles down to the nanoscale. Propell. Explos. Pyrotechn. 29 (2004) 137-145. https://doi.org/10.1002/prep.200400045

[49] B. Rannou, F.J. Velasco, S. Guzman, V. Kolarik, F. Pedraza, Aging and thermal behavior of a PVA/Al microspheres slurry for aluminizing purposes. Mater. Chem. Phys. 134 (2012) 360-365. https://doi.org/10.1016/j.matchemphys.2012.03.002 